www.jmscr.igmpublication.org

Impact Factor (SJIF): 6.379

Index Copernicus Value: 71.58

ISSN (e)-2347-176x ISSN (p) 2455-0450

crossrefDOI: https://dx.doi.org/10.18535/jmscr/v6i7.199

Journal Of Medical Science And Clinical Research

\title{
Electrocardiographic abnormalities in patients with acute stroke attending a rural hospital
}

\author{
Authors \\ R B Rame Gowda ${ }^{1}$, Manojkumar B K ${ }^{2}$, Yash Khanvilkar ${ }^{3}$, Srikanth Goud Mallam ${ }^{4}$ \\ ${ }^{1}$ Assistant Professor, Department of Medicine, Adichunchanagiri Institute of Medical Sciences \\ Balagangadharanatha Nagara, Nagamangala, mandya-571448, Karnataka, India \\ ${ }^{2,3,4}$ Post Graduate, Department of Medicine, Adichunchanagiri Institute of Medical Sciences \\ Balagangadharanatha Nagara, Nagamangala, Mandya-571448, Karnataka, India
}

\begin{abstract}
Objectives: To study the incidence of electrocardiographic changes seen in acute stroke, to know the nature of electrocardiographic changes seen in different types of stroke and the prevalence of electrocardiographic changes in acute stroke.

Method: 100 patients of acute stroke were taken and ECG was recorded in these patients at the time of admission. Follow up of admitted patients were done by serial ECG monitoring to look out for any fresh ECG changes and development of any arrhythmias for a period of 7 days.

Result: Among 100 patients (male: female-55:45), cerebral thrombosis was the most common cause seen in 56 patients and least common cause is cerebral venous thrombosis seen in 2 patients. Abnormal ECG changes were seen in 80 patients in which ST segment depression being the most common (29\% of patients).

Conclusion: Patents with cerebrovascular accidents often have abnormal electrocardiogram in the absence of known organic heart disease or electrolyte imbalance. These ECG changes are more common in cerebral thrombosis and cerebral haemorrhage. The ECG changes are presumed to be due to brainstem interference and excessive sympathetic activity. This study will provide insight in prognosis and management of acute patients.

Keywords: stroke, cerebrovascular accident, ECG.
\end{abstract}

\section{Introduction}

Most cerebrovascular diseases are manifested by sudden onset of focal neurological deficits and is defined by abrupt onset of focal neurologic deficit that is attributable to a focal vascular cause ${ }^{1}$.

Approximately 200000 deaths in United States are due to neurologic disability. A comparative study of stroke between India and other countries showed that Indians are more susceptible ${ }^{2}$.
Many studies have shown close relationship between cerebrovascular accident and cardiovascular disease. Physicians have known for centuries that primary cardiac disorder can lead to stroke, but the realization that stroke can produce cardiac abnormalities is much more recent ${ }^{3}$. Cerebrovascular accident can cause abnormal ECG even in patients without heart disease ${ }^{4}$. In view of above speculations, the objectives of 
present study is to identify the electrocardiographic changes produced primarily due to cerebrovascular accidents.

\section{Materials and Methods}

The study was conducted in Adichunchanagiri Institute of Medical Sciences B G Nagara, among 100 patients (>18 years) with cerebrovascular accidents in whom ECG was taken during the arrival of the patient in the emergency ward. Follow up ECG was done at 7 days for further changes.

Cases of head injury, primary cardiac illness, patients presenting after 72 hours of focal neurologic deficit and those with hepatic/renal disorders were excluded from the study. The study conducted was observational and analytical type analysed by descriptive statistic by means of percentage and proportions.

Patients were included in the study after confirming the diagnosis of acute stroke by NCCT Brain (with diffusion weighted imaging).

\section{Results}

Of the 100 patients 55 were male $(55 \%)$ and 45 were female $(45 \%)$. Incidence of stroke was found to be more between 61-70 years of age group (31\%) (table-1). Most common cause was found to be cerebral thrombosis (56\%) followed by cerebral haemorrhage $(28 \%)$ and least common was cerebral venous thrombosis (2\%) (table-2). Hypertension was the most common risk factor associated (63\%) followed by diabetes (19\%) and history of recurrent stroke was present in $21 \%$ of individuals (table-3). Most common ECG abnormality was found to be ST segment depression in 29 patients (29\%) followed by $\mathrm{T}$ wave inversion in 26 patients (26\%), QTc prolongation in 25 patients $(25 \%)$, $\mathrm{U}$ wave prominence seen in 22 patients (22\%), tachycardia seen in 20 patients (20\%), P wave abnormalities and PR interval abnormalities seen in 11 patients each(11\% each), ST segment elevations seen in 7 patients $(7 \%)$ and tall $\mathrm{T}$ waves being the least common finding seen in 6 patients $(6 \%)$ (table- 4$)$.
Table 1: Age and sex distribution

\begin{tabular}{|l|c|c|c|c|}
\hline Sl. no & $\begin{array}{c}\text { Age group } \\
\text { (years) }\end{array}$ & Male & Female & $\begin{array}{c}\text { Percentage } \\
(\mathbf{\%})\end{array}$ \\
\hline 01 & $18-20$ & 00 & 01 & 01 \\
\hline 02 & $21-30$ & 02 & 01 & 03 \\
\hline 03 & $31-40$ & 06 & 03 & 09 \\
\hline 04 & $41-50$ & 11 & 05 & 16 \\
\hline 05 & $51-60$ & 13 & 09 & 22 \\
\hline 06 & $61-70$ & 15 & 16 & 31 \\
\hline 07 & $71-80$ & 04 & 06 & 10 \\
\hline 08 & $81-90$ & 03 & 03 & 06 \\
\hline 09 & $91-100$ & 01 & 01 & 02 \\
\hline Total & & $\mathbf{5 5}$ & $\mathbf{4 5}$ & $\mathbf{1 0 0 \%}$ \\
\hline
\end{tabular}

Table 2: Aetiology of Stroke

\begin{tabular}{|l|c|c|}
\hline Type of Stroke & $\begin{array}{c}\text { No of } \\
\text { patients }\end{array}$ & $\begin{array}{c}\text { Percentage } \\
(\boldsymbol{\%})\end{array}$ \\
\hline Cerebral Thrombosis & 56 & 56 \\
\hline Cerebral Haemorrhage & 28 & 28 \\
\hline Subarachnoid Haemorrhage & 06 & 06 \\
\hline Cerebral embolism & 08 & 08 \\
\hline Cerebral Venous Thrombosis & 02 & 02 \\
\hline
\end{tabular}

Table 3: Risk factors in Stroke

\begin{tabular}{|l|c|c|}
\hline Risk Factors & $\begin{array}{c}\text { No of } \\
\text { patients }\end{array}$ & Percentage(\%) \\
\hline Hypertension & 63 & 63 \\
\hline Diabetes & 19 & 19 \\
\hline Hyperlipidaemia & 10 & 10 \\
\hline Smoking & 32 & 32 \\
\hline Alcohol & 20 & 20 \\
\hline Previous stroke & 21 & 21 \\
\hline
\end{tabular}

Table 4: Nature of ECG changes observed

\begin{tabular}{|l|c|c|}
\hline ECG changes & $\begin{array}{c}\text { No of } \\
\text { patients }\end{array}$ & Percentage(\%) \\
\hline P wave abnormalities & 11 & 11 \\
\hline $\begin{array}{l}\text { PR interval } \\
\text { abnormalities }\end{array}$ & 11 & 11 \\
\hline QTc prolongation & 25 & 25 \\
\hline ST segment elevations & 07 & 07 \\
\hline ST segment depression & 29 & 29 \\
\hline Tall T waves & 06 & 06 \\
\hline T wave inversion & 26 & 26 \\
\hline U wave prominence & 22 & 22 \\
\hline Tachycardia & 20 & 20 \\
\hline Bradycardia & 10 & 10 \\
\hline Arrhythmias & 10 & 10 \\
\hline Normal ECG & 20 & 20 \\
\hline
\end{tabular}


Table 5: Specific ECG changes in different types of Stroke

\begin{tabular}{|l|c|c|c|c|c|c|}
\hline ECG changes & $\begin{array}{c}\text { Cerebral } \\
\text { Thrombosis }\end{array}$ & $\begin{array}{c}\text { Cerebral } \\
\text { Haemorrhage }\end{array}$ & $\begin{array}{c}\text { Subarachnoid } \\
\text { Haemorrhage }\end{array}$ & $\begin{array}{c}\text { Cerebral } \\
\text { embolism }\end{array}$ & $\begin{array}{c}\text { Cerebral Venous } \\
\text { Thrombosis }\end{array}$ & Total \\
\hline P wave abnormalities & 05 & 04 & 00 & 01 & 01 & 11 \\
\hline PR interval abnormalities & 07 & 03 & 11 & 00 & 00 & 11 \\
\hline QTc prolongation & 23 & 01 & 01 & 00 & 00 & 25 \\
\hline ST segment elevations & 03 & 03 & 01 & 00 & 00 & 07 \\
\hline ST segment depression & 18 & 07 & 02 & 02 & 00 & 29 \\
\hline Tall T waves & 04 & 02 & 00 & 00 & 00 & 06 \\
\hline T wave inversion & 16 & 06 & 01 & 02 & 01 & 26 \\
\hline U wave prominence & 18 & 04 & 00 & 00 & 00 & 22 \\
\hline Tachycardia & 13 & 04 & 00 & 02 & 01 & 20 \\
\hline Bradycardia & 09 & 01 & 00 & 00 & 00 & 10 \\
\hline Arrhythmias & 06 & 03 & 00 & 01 & 00 & 10 \\
\hline Normal ECG & 06 & 09 & 01 & 03 & 01 & 20 \\
\hline
\end{tabular}

\section{Discussion}

Stroke is one of the leading cause of mortality. Although there was a lack of unanimity, several factors have been reported to increase risk of stroke. Shaper et $\mathrm{al}^{5}$ concluded that hypertension, cigarette smoking and pre-existing IHD was found to be major risk factors.

In present study among 100 patients of 18-94 years age group male to female sex ratio was 1.2:1 which is comparable to other studies done by Anand et $\mathrm{al}^{6}$ (1.7:1) and Nagaraja et $\mathrm{al}^{7}$ (2:1). Most common age group being $5^{\text {th }}$ and $6^{\text {th }}$ decade (71\%) which is comparable to $\mathrm{Carlo}^{8}$ study $(71.8 \%)$.

Hypertension was present in majority of cases (63\%) which is comparable to studies done by Pundiyan U et $\mathrm{al}^{9}(88 \%)$, Smith $^{10}(87 \%)$ and $\operatorname{Carlos}^{8}$ (48\%).

In this study, $66 \%$ patients had ischemic stroke which is comparable with Kuruvilla et $\mathrm{al}^{11}$ $(57.3 \%)$ and Roy et $\mathrm{al}^{12}(71 \%)$.

Vast majority of stroke patients demonstrated ECG changes in current study which is comparable with studies of Goldstein ${ }^{13}$ and Bozluolclay ${ }^{14}$. Increased QTc in our study seen in $25 \%$ of cases is comparable with study of Goldstein $^{13}(32 \%)$. T wave inversion was seen in $26 \%$ in the present study, whereas $15 \%$ was seen in study by Goldstein et $\mathrm{al}^{13}$. ST segment depression was seen in $29 \%$ in present study whereas $13 \%$ was seen in study by Goldstein et $\mathrm{al}^{13}$. U waves were seen in $22 \%$ which was comparable to study done by Goldstein et $\mathrm{al}^{13}$
(28\%). Sinus Tachycardia seen in $20 \%$ of cases in present study whereas $2 \%$ seen in Goldstein et $\mathrm{al}^{13}$ study.

Sinus Bradycardia was seen in $10 \%$ in present study whereas $8 \%$ was seen in Goldstein et $\mathrm{al}^{13}$ study. Arrhythmia was seen in $10 \%$ in present study whereas $25 \%$ was seen in Goldstein et $\mathrm{al}^{13}$ study.

\section{Conclusion}

Cerebrovascular accident is a major cause of morbidity and mortality and the incidence increases with advancement of age. Patients with cerebrovascular accidents often have abnormal electrocardiogram in the absence of known organic heart disease or electrolyte abnormalities. In clinical practice ECG changes in stroke can be misinterpreted as myocardial ischemia / infarction and thereby knowledge of these changes are necessary for efficient management.

\section{References}

1. Charles Wiener MD, Kasper DL, Fauci AS, Stephen L, Hauser MD, Longo DL, Loscalzo J. Harrison's Principles of Internal Medicine Self-Assessment and Board Review.

2. Adams RD, Victor M, Ropper AH. Principles of Neurology. 6th. Edition. Singapore, McGraw-Hill Book Co. 1997:603-5.

3. Goldstein DS. The electrocardiogram in stroke: relationship to pathophysiological 
type and comparison with prior tracings. Stroke. 1979 May 1;10(3):253-9.

4. Phornphutkul C, Rosenthal A, Nadas AS, Berenberg W. Cerebrovascular accidents in infants and children with cyanotic congenital heart disease. American Journal of Cardiology. 1973 Jan 1;32(3):329-34.

5. Shaper AG, Phillips AN, Pocock SJ, Walker M, Macfarlane PW. Risk factors for stroke in middle aged British men. Bmj. 1991 May 11;302(6785):1111-5.

6. Anand K, Chowdhury D, Singh KB, Pandav CS, Kapoor SK. Estimation of mortality and morbidity due to strokes in India. Neuroepidemiology. 2001;20(3): 208-11.

7. Nagaraja D, Gururaj G, Girish N, Panda S, Roy AK, Sarma GR, Srinivasa R. Feasibility study of stroke surveillance: data from Bangalore, India. Indian Journal of Medical Research. 2009 Oct 1;130(4):396.

8. Di Carlo A, Lamassa M, Baldereschi M, Pracucci G, Basile AM, Wolfe CD, Giroud M, Rudd A, Ghetti A, Inzitari D. Sex differences in the clinical presentation, resource use, and 3-month outcome of acute stroke in Europe: data from a multicenter multinational hospital-based registry. Stroke. 2003 May 1;34(5):1114-9.

9. Pandiyan U, Arjundas G, Arjundas D. Risk factors and stroke outcome-An Indian Study. Hypertension. 2005;289:71-9.

10. Smith. Neurology, Volume 65(6); September 27.2005:855-58.

11. Kuruvilla T, Bharucha NE. Epidemiology of stroke in India. Neurol J Southeast Asia. 1998;3:5-8.

12. Roy MK. ECG changes in cerebrovascular accident-A prognostic parameter. JAPI. 1995;43:12-4.
13. Goldstein DS. The electrocardiogram in stroke: relationship to pathophysiological type and comparison with prior tracings. Stroke. 1979 May 1;10(3):253-9.

14. Bozluolcay M, Ince B, Celik Y, Harmanci $\mathrm{H}$, Ilerigelen B, Pelin Z. Electrocardiographic findings and prognosis in ischemic stroke. Neurology India. 2003 Oct $1 ; 51(4): 500$. 